\title{
Investigation of documentation processes of students with low and high level of mathematical literacy: A case study
}

\author{
Kübra Ada1, Menekşe Seden Tapan Broutin², Gül Kaleli Yılmaz ${ }^{3}$ and Gül Mine Bayram ${ }^{4}$ \\ ${ }^{1}$ Bursa Uludag University, Turkey (ORCID: 0000-0001-6243-9703) \\ ${ }^{2}$ Bursa Uludag University, Turkey (ORCID: 0000-0002-1860-852X) \\ ${ }^{3}$ Bursa Uludag University, Turkey (ORCID: 0000-0002-8567-3639) \\ ${ }^{4}$ Bursa Uludag University, Turkey (ORCID: 0000-0003-3468-0756)
}

\begin{abstract}
The aim of this study is to analyze and compare the documentation processes of students with low and high mathematical literacy levels. To this aim, a qualitative research design was adopted. Participants in this case study consisted of two students studying at the $9^{\text {th }}$ grade who were selected through the criterion sampling method considering the mathematical literacy levels (low and high). The participants were asked to draw and explain a schematic representation of the resource system that they employed in their mathematics learning process. They also completed 30-day mathematics learning diaries, which required them to explain the activities they did and the resources they used. Interviews were scheduled as the secondary data collection tool. Both content analysis and descriptive analysis were used to analyze the data. As a result, differences in resource usage schemes were found in the mathematics learning processes of two the participants. Compare to the student with low mathematical literacy, the objective of the action component of the utilization scheme for the student with high mathematical literacy was determined to be to associate mathematical knowledge with daily-life.
\end{abstract}

Keywords: Documentational approach; Documentation process; Mathematical literacy; $9^{\text {th }}$ grade students

Article History: Submitted 13 July 2021; Revised 23 November 2021; Published online 31 December 2021

\section{Introduction}

Mathematical literacy is an important tool that enables one to connect mathematics with daily life and solve real-life problems mathematically (McCrone \& Dossey, 2007). It requires the functionalization of mathematical facts and concepts and their evaluation in the context of real life. The development of students' mathematical literacy levels has an important place at schools; it is also among the general objectives of the mathematics curriculum (Ministry of National Education, 2019). For this reason, the ability of individuals to produce mathematical solutions to the problems they encounter in real life and to make mathematical knowledge functional by associating it with

Address of Corresponding Author

Kübra Ada, Mathematics Education Doctorate Program, Institute of Educational Sciences, Bursa Uludag University, 16120, Bursa, Turkey.

$\triangle$ kubrada.16@gmail.com

How to cite: Ada, K., Tapan Broutin, M. S., Kaleli Yılmaz, G., Bayram, G. M. (2021). Investigation of documentation processes of students with low and high level of mathematical literacy: A case study. Journal of Pedagogical Research, 5(4), $189-213$. https://dx.doi.org/10.33902/JPR.2021474615 
life has become the current purpose of mathematics teaching (Altun et al., 2018). So, some student assessment programs (Program for International Student Assessment [PISA]) conducted on an international platform are based on students' mathematical literacy levels.

Program for International Student Assessment [PISA], one of the programs for international student assessment, assesses students in the age group of 15 by measuring their literacy skills in science, mathematics and mother tongue. The education levels of many countries are compared according to the results from PISA. For this reason, studies on improving students' mathematical literacy skills have increased (Altun \& Bozkurt, 2017). In many studies in the literature, students' mathematical literacy levels have been evaluated in many contexts, such as countries' education policies, teacher training programs, and teaching methods. Rautalin and Alasuutari (2009) examined Finland, one of the top countries in PISA success rankings, and determined that government policy significantly impacted PISA success. Eraslan (2009) attributed the success of Finland to the teacher training system in the country. Akyüz and Pala (2010) compared Turkey, Greece and Finland, which had different levels of success in PISA. As a result of the study, it was determined that variables such as working in groups, attitude, and class discipline were effective on success. According to PISA results in the literature, comparing and evaluating countries with different success levels in terms of many factors provided important information for mathematical literacy (Serçe \& Acar, 2021). However, the mathematical literacy levels of the students who continue the educational process in the same country and under the same conditions may differ from each other. In this case, it is emphasized that students' mathematical literacy levels can also be affected by their individual factors of the students in addition to the factors such as the teacher, teaching method, and system of education. In the study conducted by Yilmazer (2015), it was revealed that there is a significant relationship between students' arithmetic performance and their mathematical literacy. This means that students with high arithmetic operation skills may also have high mathematical literacy. However, it is noteworthy that there are students who do not show similar performance at the level of mathematical literacy despite their high arithmetic skills and mathematics achievement (Yeğit, 2019). This situation shows that some students have high mathematical literacy by going beyond their mathematical knowledge and arithmetic operation skills, while some of them cannot do this sufficiently. The fact that this difference occurs in students taught by the same teacher in the same class suggests that the student's learning process may also be effective in developing mathematical literacy.

Although students receive education under similar conditions, most of their learning processes are carried out through individual studies. Students' resources in the mathematics learning process, the purposes of using these resources, and the operational invariants behind them may differ. In this process, the students' resources and resource usage schemes can strengthen the link between mathematical knowledge and real-life context. For this reason, it is thought that the difference in the mathematical literacy levels of two students with high mathematics achievement may be due to the use of resources in the students' resource system that contributes to associating mathematical knowledge with life. Mathematical literacy requires students to perform arithmetic operations and recognize mathematical problems in the context of real life, and express them mathematically (Sat1c1, 2008). Gellert (2004) stated that the learning process using daily life problems contributes to gaining mathematical literacy. Martin (2007), on the other hand, criticized students' processes of learning mathematics by rote away from real life and suggested a process of learning mathematics intertwined with life. In this direction, it is thought that the documentation system consisting of both social resources and written resources, visual resources, that students use in the learning process can shape mathematical literacy. Thus, it is essential to examine the documentation processes of the students and to reveal the differences in the resource systems of the students in the development of mathematical literacy. For this purpose, it is critical for this study to determine the students with high mathematics achievement but different mathematical literacy levels and examine their documentation processes. It is expected that the mathematical literacy levels of two students with high and low mathematics achievement (Y1lmazer, 2015) and 
their document systems will differ significantly. In this direction, within the study's scope, it was aimed to examine and compare the documentation processes of two students with high mathematics achievement and different mathematical literacy levels. In line with the results obtained from the study, it makes the study crucial that the function of the documentation process of the students on mathematical literacy was analyzed, and it gained a different perspective on the subject. It is thought that determining the resources that support the development of mathematical literacy and the use schemes of these resources will primarily guide teachers and students in arranging classroom teaching practices and shaping students' resource systems. In addition, examining the prominent types of resources in the resource system of a student with high mathematical literacy and the reasons for using these resources can shed light on the determination of curriculum requirements for mathematical literacy and the arrangement of mathematics course books. For this reason, it is considered necessary and important to examine the resources used by students with different mathematical literacy levels in the mathematics learning process and reveal and examine significant differences in them. However, no research has been found in the literature that examines students' mathematical literacy skills in the documentation processes related to their resources, although there are many kinds of research on mathematical literacy. In this direction, within the scope of the study, the documentation processes of students with low and high mathematical literacy levels were examined in-depth and also compared.

\subsection{Conceptual Framework}

\subsubsection{Mathematical literacy}

Mathematical literacy is defined as the capacity of an individual to formulate, use and interpret mathematics in different contexts (Organisation for Economic Cooperation and Development [OECD], 2010). By mathematical literacy, students think about how mathematics can be used in real life and can benefit from mathematics in meeting their needs in the context of real life (Ersoy, 1997). In this respect, mathematical literacy helps individuals realize the role of mathematics in real life and make decisions based on justifications (Altun et al., 2018). Mathematical literacy consists of three mathematical processes: 1) Formulating situations mathematically, 2) using mathematical concepts, facts, and processes, and 3) interpreting, applying and evaluating mathematical outputs (OECD, 2019, p. 77). These processes are interconnected with each other and form the modelling cycle as presented in Figure 1.

Figure 1

Model of mathematical literacy

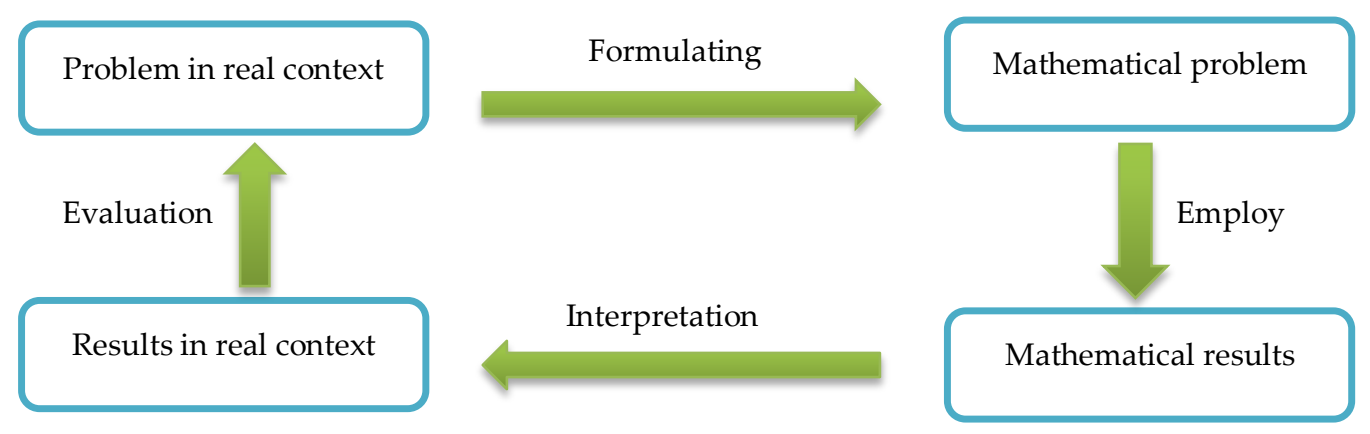

In the process of formulating situations mathematically in Figure 1, variables and relationships in the context of real life are transformed into a mathematical structure. This transformation process requires the real-life model to be transferred to the mathematical world using appropriate mathematical representations. The process of using (employing) mathematical concepts, facts, and processes takes place in the world of mathematics and is a mental process where competencies such as using mathematical language and operations and representation are dominant. In the process of 
interpreting, applying and evaluating mathematical outputs, the mathematical results obtained in the process of using mathematics are interpreted in the context of the problem, and the significance of this interpretation in the context of real life is evaluated (Kabael, 2019). In a nutshell, in the mathematical literacy modeling cycle, the individual analyzes the situations in real life by transferring them to the world of mathematics and then evaluating the mathematical information obtained by interpreting it in real life. For this cyclical process to proceed effectively, the individual must establish a connection between mathematics and real life along with the operations s/he performs in the world of mathematics. In this respect, international exams such as PISA measure how students use their knowledge in the context of social life problems rather than what they know (Ak1lli, 2020).

Although students have high mathematics achievement, their mathematical literacy levels may differ from each other. The type of questions asked to students in the exams held in schools primarily measure mathematical operation skills (Fatih \& Bekdemir, 2017). This situation directs the student primarily to process the learned information in the world of mathematics. In the learning process, the need for students to make a connection between mathematical knowledge and real-life situations may remain in the background. On the other hand, some students can connect the real-life context and the world of mathematics by differentiating the learning process with their resource usage scheme. The student's resources (written, visual, environmental, social, etc.) in this process can go beyond the student's arithmetic skills and improve his/her mathematical literacy level. Hence, it is thought that the resources used by the students and the resource usage schemes may be effective in that students with the same mathematics achievement in terms of mathematical knowledge and arithmetic skills have different mathematical literacy levels. Thus, it is necessary to examine the documentation processes of students who have high mathematical achievement but whose mathematical literacy differs significantly. In the literature, individuals' resources and resource usage schemes can be examined within the Documentational Approach to Didactics scope. This approach focuses on determining why individuals prefer these resources and determining the operational invariants (theories and concepts) behind this reason, beyond identifying the resources that individuals use. Additionally, with this approach, the coordination between the resources used by the individual and the resulting resource system can be analyzed. This study aims to determine the resources used by students with low and high mathematical literacy and to analyze the coordination between these resources. In addition, since it was aimed to examine and compare the students' purposes of using these resources and the operational invariants behind them, the study was carried out based on the Documentational Approach to Didactics.

\subsubsection{The documentational approach to didactics}

The Documentational Approach to Didactics (DAD), first introduced by Gueudet and Trouche (2009), focuses on the interaction between the individual and resource and the results of this interaction. In $\mathrm{DAD}$, teachers' interactions with the resources they use in the teaching process are generally examined. It is accepted that this interaction is related to the professional knowledge and beliefs of the teachers (Cooney, 1999). However, recently, DAD is also used in studies aiming to examine the interaction of students with the resources they use in the learning process (Kock \& Pepin, 2018). The resource systems of the students, the reasons for choosing these resources, the interaction between the resources and the student can be discussed in detail within the scope of DAD.

The concept of resource has a very broad meaning within the scope of the documentational approach to didactics. A resource can consist of social factors such as social media and interaction with friends and a textbook, students' worksheets, software programs, etc. (Sarığlu, 2020). All resources used by the individual form the resource system.

While individuals are in the process of interacting with a certain resource or resource system, they develop some schemes for the use of that resource (Trouche et al., 2019). These schemes are 
unique to each individual and are shaped in line with the tendency and knowledge of the individuals. For this reason, the schemes developed by individuals may differ even though they use the same resource (Baştürk-Şahin et al., 2020). According to Vergnaud (1998), the concept of the scheme is an unchanging organization of activities that guides the activity and incorporates the knowledge and ideas that emerge from that activity for a given class of situations. In the analysis of this process, the key to any theory is the couple situation/scheme: dialectical pair if there is one, because one does not have one without the other. Suppose I underline the dialectical orientation of my reasoning. In that case, it is not only for thought reasons; it is also because, in the analysis of the conceptualization processes, one often led to distinguish and connect at the same time complementary concepts. It is the case for concept and theorem, and therefore for concept-in-act and theorem-in-act. They must be distinguished since a theorem (hear a proposition) can be true or false, while a concept cannot. At the same time, there is no theorem without a concept and no concept without a theorem (Guertin, 2012). There are four components in a scheme (Gueudet \& Trouche, 2009; Gueudet, 2017; Vergnaud, 1989):

$>$ Expectations or predictions: They concern the effect to be obtained, resulting from inferential calculations;

$>$ Operational invariants: There are observable aspects as well as unobservable aspects in the usage of a resource. The invisible aspects of resource usage, namely the cognitive structure that directs the action, are called operational invariants. They are also the instruments for conceptualizing the reference situations in the domain considered. A theorem in action is a proposition accepted by the person as accurate for similar goals. On the other hand, the concept in action refers to the concept that the person accepts as related to similar goals.

$>$ Action rules: Action rules make it possible to decide on the actions to be taken and which, at the same time, result from inferential calculations. These are the rules of action that generate the sequence of actions;

$>$ Inferences: Inferences take the form of calculations from the information provided by the situations and from the computational qualities of the invariants.

The schemes considered within the documentational approach reveal the use of a particular resource for a particular purpose. These are named usage schemes. The resources used by the individual go through the documentation process depending on the usage schemes. The new resources created resulting from this process are called documents (Gueudet \& Trouche, 2009). In a different viewpoint, the document consists of the combination of the resource and the usage scheme of the resource. In this context, it can be said that a document is much more than a list of resources. The document can formulate the relationship between the resource and usage schemes (Gueudet \& Trouche, 2011, pp. 25).

\section{Document $=$ Resources + Scheme of utilisation}

The purpose of the action, action rules, and operational invariants is effective when students choose their resources in the learning process. For this reason, although students take lessons from the same teacher and use similar resources, their resource usage schemes and documents may differ from each other. This may affect students' academic success and skills. The resource usage schemes and documents of the students with different mathematical literacy levels may differ despite high mathematics achievements. It is thought that the resources and usage schemes used in the learning process will play an important role in associating mathematics with life.

\subsection{The Aim}

This study examines and compares the documentation processes for learning mathematics of the students with high mathematics achievements and different mathematical literacy levels. In this direction, it is aimed to determine the resources used by two students with low and high mathematical literacy levels in the mathematics learning process and to reveal the components of 
the usage schemes of these resources. In line with this general purpose of the research, answers to the following questions were sought:

1. For the student with a low mathematical literacy level;

a) What are the resources used in the learning process of mathematics?

b) What are the action rules and operational invariants of the usage schemes of the resources used in the learning process of mathematics?

2. For the student with a high mathematical literacy level;

a) What are the resources used in the learning process of mathematics?

b) What are the action rules and operational invariants of the usage schemes of the resources used in the learning process of mathematics?

3) What are the similarities and differences in the documentation process of mathematics learning for the two students with high and low mathematical literacy levels?

\section{Method}

\subsection{Research Design}

This qualitative research is designed as a holistic multiple case study, one of the case study types. The case study is a research method that aims to introduce the case studies examined to illuminate some general theories and mostly seeks answers to the questions "how?", "why?", and "what?". Case studies focus on a spesific case, which can sometimes be an event, sometimes a person or a group (Çepni, 2007). In holistic multi-case studies, one of the case types, independent cases are selected, and each case is perceived as a whole, and comparisons can be made among the cases (Yin, 2013). Since this research aimed to examine and compare the documentation processes of the students with different mathematical literacy levels, the research model was chosen as a holistic multiple case study.

\subsection{Participants}

The research participants consisted of two students studying at the 9th grade level (15 years old) of secondary education in the 2020-2021 academic year in a province in the west of Turkey. The school which students study is one with a medium-level socio-economic condition. The criterion sampling method, one of the purposive sampling methods, was used to determine the participants. The criterion sampling method is the selection of individuals who meet the criteria determined in line with the purpose of the research as the sample of the research (Patton, 2005). In this study, four criteria were taken as basis in the process of determining the participants. These criteria are; the students' "high academic achievement scores of the mathematics course at the end of the term", "different mathematical literacy levels (low-high)", "voluntary participation in the research," and "students who are expected to present rich data". In this direction, first of all, a student group with high academic achievement scores of the mathematics course at the end of the term was determined. Then, a test consisting of 15 mathematical literacy questions was prepared to determine the students' mathematical literacy levels. The questions in this test were selected from the questions prepared and published by PISA. Expert opinion was taken to select the questions. Attention was paid because the questions required different mathematical literacy skills (reasoning and argumentation, strategy generation, representation proficiency, etc.). The prepared test was applied to the students with high mathematics achievement and volunteered to participate in the research.

The research participants were formed by choosing one student for each group from among these students, who were thought to provide rich data by actively participating in the research by their mathematics teachers and whose mathematical literacy levels were significantly different from each other (low-high). While evaluating the students' mathematical literacy levels, the processes in the mathematical literacy cycle were taken into account. The student, considered to have low mathematical literacy, correctly answered the questions requiring a mathematical result by using the mathematical formulas and operations given in the question (employ). However, 
s/he could not answer the questions that required him/her to switch from real-life context to mathematical expressions and symbols (formulation) and the questions that required him/her to interpret and evaluate mathematical results in a real-life context (interpretation and evaluation). When the student is asked the reason for leaving these questions unanswered; s/he stated that $\mathrm{s} /$ he had no idea about the solution and could not reason about it. The participant, who was considered to have high mathematical literacy, answered each of the questions correctly and was able to carry out the processes in the mathematical literacy cycle on the questions. By creating mathematical models, s/he was able to transition from the real-life context to the world of mathematics and reach mathematical results by employing mathematical problems. In addition, $\mathrm{s} /$ he was able to adapt the mathematical knowledge $\mathrm{s} /$ he obtained to the real-life context, defend and evaluate his/her reasoning with written statements based on logical justifications. In the test directed in this direction, the mathematical literacy level of the participant who can perform all the processes in the mathematical literacy cycle by using the necessary skills and reaching the correct results was accepted as high. The participant who could only answer the questions that required the process of employ, but could not find solutions to the questions that required formulating, interpretation and evaluation using mathematical skills, despite having high achievement in mathematics, was considered to have low mathematical literacy.

In this study, the participant with the low mathematical literacy level was coded as "P1", and the participant with the high level was coded as "P2". P1 and P2 are female students and take lessons in the same class. The school in which the participants study is a high school with a high level of success, which admits students with central exam scores. The reason for this, the mathematical literacy of students who have higher achievements in mathematics according to their arithmetic operation skills is also higher (Yllmazer, 2015). In this direction, it is necessary to reduce the determinant effect of mathematics achievement on mathematical literacy to obtain precise and reliable results by examining the difference in the mathematical literacy level of the students in the context of DAD. For this reason, it is aimed to select students who have high achievement in both the school and individual mathematics achievement and who have different mathematical literacy levels.

\subsection{Instruments}

Data triangulation was performed through collecting data from multiple sources. In this sense, data collection process was carried out through a semi-structured interview form, a mathematics learning diary, photographs of the working environment and the resources used, and clinical interviews. These data collection tools aimed to determine the participants' documents and reveal the components related to the resource usage schemes. Information on data collection tools is presented below.

\subsubsection{Semi-structured interview form}

The semi-structured interview form consists of 5 open-ended questions aiming to determine how students design the mathematics learning process, what documents they use/support in this process, and what documents help them associate mathematical knowledge with life. Some of the questions in the interview form are: "What are the resources (written and printed resources, people you get support from, environment-institution, technology-software, visual argument, etc.) that you use/get support from in the process of learning mathematics? What is your reason for choosing these?", "Do you try to associate the mathematical information you learned in the lesson with life? Why?" Additionanally, in the interview form, the students were asked to draw and explain the schematic representation of the resource system they used in the mathematics learning process. In this way, it is aimed to reveal the association that the participants have created between the documents they use with their usage schemes. In preparing the interview questions, the expert opinion of an academician who has knowledge and experience about the documentational approach was taken. 


\subsubsection{Math learning diary}

Learning diaries have been created that require the student to explain topics such as the mathematics learning process she does during the day, the activities she does, the resources she uses, and the study's duration. The diaries are designed under three main themes: "The activities and studies I do about mathematics today", "The resources I use in my mathematics learning process today (written, visual, technological, etc.)," and "Mathematics study time". At the same time, it is aimed to reach detailed information by creating categories under these themes. Expert opinion was sought in the preparation of the diaries. The students were asked to keep these diaries regularly for 30 days, and the process was followed closely. Thus, it is aimed to support the data obtained from the semi-structured interviews and reveal the documents, if any, that were not specified during the interview.

\subsubsection{Photos of the working environment and the documents used}

To realize a reflective investigation about the participants' documentation processes for learning mathematics, photographs of the participants' study rooms and libraries were taken. In addition, the photographs of these documents were also accessed to obtain information about the content of the documents (written, visual, technological, etc.) that the participants stated in the semistructured interviews and the mathematics learning diaries.

\subsubsection{Clinical interview}

At the end of the data collection process, holistic analyses were conducted on the schematic representation of the source system created by the participants, the data obtained from the semistructured interviews, the mathematics learning diaries, and the images reflecting the working environment. Through examining the data obtained from different data collection tools, we noted the details that attract attention and need to be examined in depth by reaching more detailed information, and created clinical interview questions. Thus, it is aimed to reveal the operational invariants related to the resource usage schemes of the participants. For example, when the photos taken from P1's study desk were examined, it was noteworthy that the test book recommended by his/her teacher was on the study desk. The clinical interviews examined whether this book was constantly on the table and whether it had a justification. Thereupon, P1 stated that while choosing the test books to use, she preferred the books recommended by the mathematics teacher and her sister and kept them on her desk for easy access. So, it was detected that mathematics teacher and sister resources, two significant environmental resources for P1, also play a guiding role in determining written resources. In addition, P2 grouped the resources she used in the mathematics learning process by dividing them into specific categories in the SRRS she drew. She also created links between these resource groups with one-way and two-way arrows. This situation was remarkable, and a clinical interview was conducted to collect in-depth data on what the one-way and two-way arrows meant. In the clinical interviews, the researcher and the participant had the following dialogue regarding the meaning of these connections:

Researcher: In the SRRS, some sources include one-way arrows and some two-way arrows. Is there any special meaning in the use of these arrows?

P2: Yes, there is. Resources with double-sided arrows are actually interconnected.

Researcher: What kind of connection is there? For example, can you explain the connection between test books and internet resources?

P2: For example, if there are questions that I can't solve in the test books, I look at the subject summaries on the Internet. When I remember the subject, I immediately go back to the test book. Or I solve questions about the subject I listen to on Youtube in my test book.

Researcher: So what does the bidirectional connection between the "I" resource and the "environmental resources" mean?

P2: For example, when there are questions that we cannot solve with my friend, we tell each other. Or we discuss where we can use that subject while studying math with my brother. But since the test books only contributed to me, I showed it with a one-way arrow. 
Each resource specified in the SRRS was related to the "I" resource, and these resources supported the "I" resource. In addition, there was a mutual interaction between P2 and environmental resources. In other words, P2 was affected by environmental resources and affected resources. Besides, it was determined that the double-sided arrow used between test books and internet resources meant that both took place in a loop.

\subsection{Data Collection Process and Researcher's Role}

The data collection process of the study lasted for 31 days. Before starting the data collection process, the interviews were held with each participant, and detailed information about the purpose of the research and data collection tools was presented. At this stage, the voluntary participation status of the participants was reconfirmed, and their consents were obtained. At the beginning of the data collection process, semi-structured interviews were conducted with the participants. These interviews were held in video conferences with each participant in an online environment and were recorded with the participants' permission. In this process, the researcher avoided guiding expressions and provided an environment to allow the participants to express themselves comfortably. In the interviews, it was aimed to gather rich data by including additional exploratory questions in line with the participants' explanations. When there were incomprehensible or unclear expressions in the participants' explanations, the participants were asked to explain again. The length of the interviews was approximately one hour, and in-depth interviews were conducted. After the interviews, the participants filled out their math learning diaries for 30 days. Before the data collection process, the participants were provided with detailed information about filling in the diaries and what should be considered. Then, the questions of the participants about the subject were answered. The participants were asked to fill in the diaries on the days they studied mathematics and deliver the reports of that day to the researcher on the same day. In this way, any errors or deficiencies (such as leaving some sections blank, giving very superficial and short information) about the use of the diaries were detected, and feedback was provided to the participant. In this direction, the repetition of the same mistake was prevented throughout the data collection process. As an example, P2 left the titles "What did I aim with this study" and "What contribution did it make" in the "Mathematics-related activities and studies I did today" section of the diary unanswered. However, these titles are significant in determining the operational invariants in the resource usage scheme. For this reason, the participant was reminded that s/he should add explanations about the subject by asking the reason for leaving these sections blank. In this process, photographs were taken of the content of some resources that the participants stated in their diaries or semi-structured interviews. In addition, photographs of their study environments and libraries were also taken, with the participants' permission to carry out a reflective analysis. All the data obtained from different data collection tools were analyzed holistically at the end of the data collection process. Clinical interviews were conducted for the data that required the participants to make additional explanations. The data collection process is presented in Figure 2.

\subsection{Data Analysis}

The data obtained from the research were analyzed by content analysis and descriptive analysis. Content analysis is an inductive method in which data is analyzed by subjecting it to a deep process (Çepni, 2007). By conducting a content analysis on the data obtained from the semistructured interviews, the categories and themes related to the resources used by the participants in the mathematics learning process were reached. First of all, codes with similar meanings were identified and grouped under inclusive categories. The categories reached as a result of content analysis within the scope of the study are as follows: Teacher, sister, brother, cousin, friend himself/herself, test books, subject summary diagrams, YouTube channels (learning), YouTube channels (question solution), cartoons, short subject summaries, other lessons. These categories were also grouped under common themes. Themes are designed for differing from each other with 
Figure 2

Data collection process

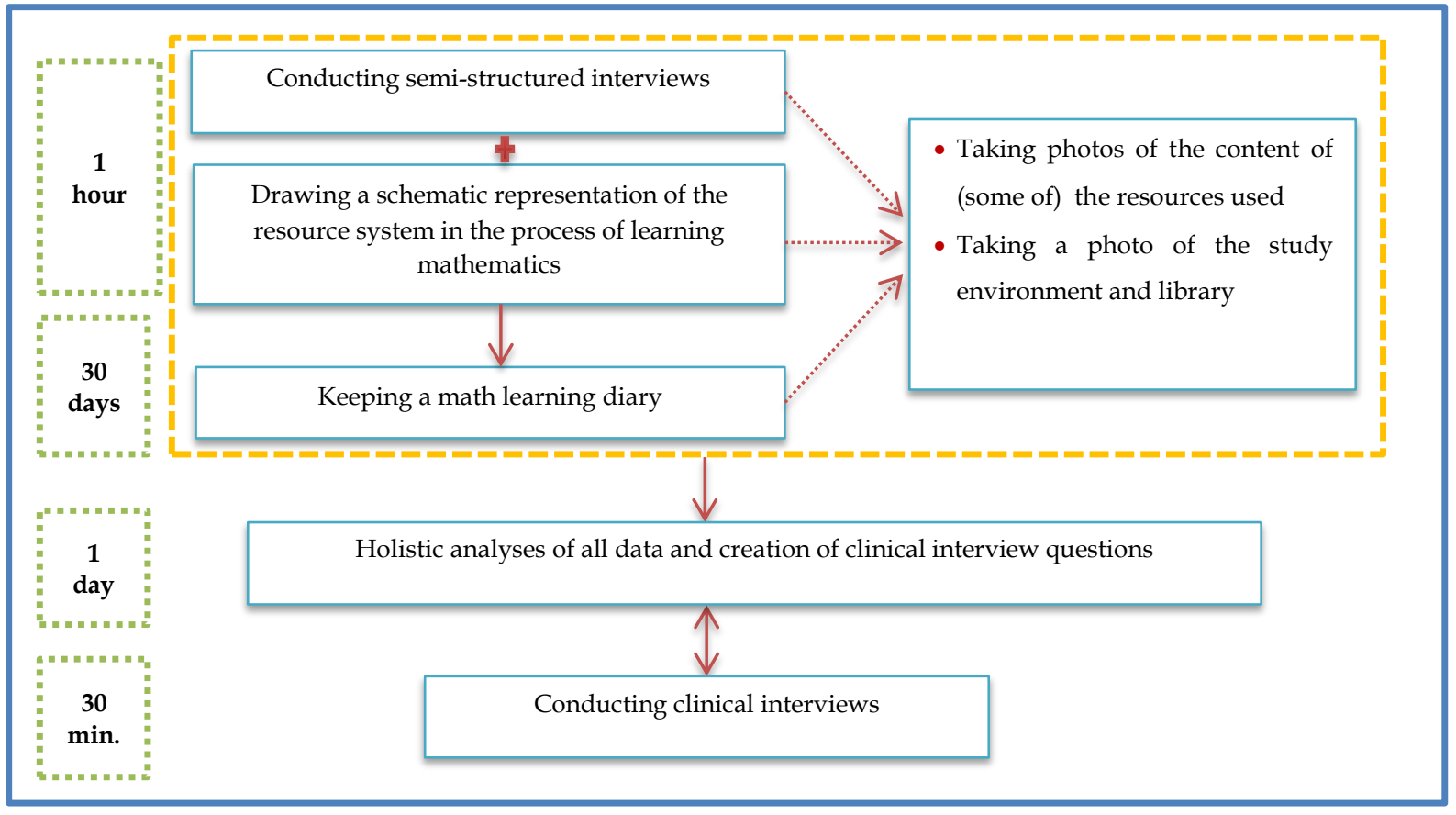

distinct features but cover the categories under them. The themes reached are individual resources, environmental resources, written resources, internet resources, visual argument resources, interdisciplinary resources. Within the scope of the study, the data obtained from the interviews and mathematics learning diaries were analyzed by making descriptive analysis to determine the components of the resource usage schemes of the participants. Descriptive analysis is a deductive analysis method in which the data are analyzed according to the themes revealed by the conceptual framework of the research or the research questions (Strauss \& Corbin, 1998).

The data obtained from the interviews and mathematics learning diaries were analyzed by making descriptive analysis to determine the components of the resource usage schemes of the participants. In the descriptive analysis process, the components of the scheme concept put forward by Vergnaud (1998) were taken as the conceptual framework. According to Vergnaud (1998), the scheme consists of four components: Purpose of an action, action rules, operational invariants (theorem in action and concept in action), and inferences. By making an in-depth analysis of the data obtained from the interviews and diaries, it was first tried to reach the aims of the student's resource usage scheme. Intensely emerging goals in the data obtained were determined, and the operational invariants behind these goals were examined. However, by determining how the participant followed to achieve this goal, the action rules in the resource usage scheme were reached. For example, when P1's statements/journal notes were examined, "finding practical solutions to problems" came to the fore through the sources she used/benefited from while studying mathematics. In line with the P1's statement "I aimed to learn easy ways to solve problems. (P1)" and similar diary notes, the purpose of the action in P1's resource usage scheme was determined as "Developing practical solutions for different types of questions." In addition, with the statements of P1; "I would like to learn how to solve the questions shortly", "I don't care about associating the mathematical knowledge in the course with life, I don't worry about what it does for me in life. The important thing is to be able to solve mathematical questions practically.", "I learned the short solution of some question forms." operational invariants of P1 that support the purpose of action were reached. P1's theorem in action belonging to the resource usage scheme was determined as "Practical solutions should be determined for each type of question. It is not so important to know what the subject is for in real life." while the concept in action was determined as "Practical solution way". In the determination of the action rules of P1, with the statement "By following the 
solved questions on the Youtube channel, I saw the solution of all kinds of problems with the short method, and then I solved the question for reinforcement." the action rule "Use Youtube channels to learn practical solutions and apply what you have learned in test books" was put forward. With the statement "My sister shows practical ways to solve questions" the action rule "Get help from your sister for the practical solution of questions." was reached.

The schematic representation of the resource system used by the participants in the mathematics learning process, the photographs of the study environment, and the data obtained from the clinical interviews were analyzed and interpreted in line with the findings obtained from the other data collection tools. The findings of the study were reported separately for each participant. Then, a comparative analysis of the codes and categories obtained from the two participants was made. During the analysis process, the researcher analyzed and interpreted the data twice in a certain time interval, and the consistency of the comments was checked.

\subsection{Credibility, Transferability, Consistency, Verifiable and Ethics}

In qualitative studies, unlike quantitative studies, instead of validity and reliability, it is recommended to use the concepts of credibility, transferability, consistency, and confirmability (Lincoln \& Guba, 1985). In this context, these concepts, which are suitable for the nature of qualitative research, were considered within the scope of the study. The quality of the study was increased by making various arrangements. To ensure credibility in the study, data triangulation was performed using different data resources (semi-structured interviews, clinical interviews, mathematics learning diaries, written and visual documents, schematic representation of the resource system) during the data collection process. To reach reliable conclusions about the documentation processes of the participants, the semi-structured interviews, the schematic representation of the source system, and the findings obtained from the mathematics learning diaries were compared and evaluated holistically. Then, these findings were supported by the findings obtained from visual documents and clinical interviews, and in-depth examinations were made. The semi-structured interviews in which questions were asked to provide detailed and clear thoughts and long-term interactions were realized. The researcher did not interfere with the answers given by the participants and avoided the statements/questions that led the participants during the interview. In addition, the findings obtained as a result of the analysis of the data and the meanings that the researcher deduced from the interviews were shared with the participants, and the participants' confirmations were obtained. To ensure the transferability of the results obtained from the study, detailed descriptions were made in the findings section, and direct quotations were included. In addition, the purposive sampling method was used to determine the participants, and the descriptive information of the participants was stated in detail. In the interviews conducted within the scope of the study, a similar approach was shown to each participant, and the interviews were recorded. During the data analysis, consistency analysis was carried out by coding twice at different time intervals. In addition, all the data collection tools, raw data, notes, written and visual documents, audio recordings of the study were archived by the researcher to increase confirmability.

Ethical rules were taken into consideration at all stages of the study to ensure research ethics. During the data collection process, the participants were given detailed information about the purpose of the research and the voluntary participation criteria were taken into consideration. In this direction, voluntary participation in the research and permission certificates were obtained from the participants and their parents. In planning the data collection calendar, ideas were exchanged with the participants, and the most convenient periods were determined for the participants. Participant consent was obtained for recording the interviews and archiving the data. The participants' identities were kept confidential within the study's scope, and the findings were reported with participant codes P1 and P2. 


\section{Results}

In this section, the results obtained from the study were first presented separately for each participant, and then the comparisons between the findings of the two different participants were included.

\subsection{Findings Regarding the Participant (P1) with a Low Mathematical Literacy Level}

In line with the first problem of the study, the resources used by the participant with low mathematical literacy level in the mathematics learning process were determined, and some components of the usage schemes related to these resources were determined. When the semistructured interviews and the mathematics learning diaries filled by the participant are examined, the findings regarding the resources used by $\mathrm{P} 1$ are presented in Table 1.

Table 1

Findings related to the resources used by $P 1$

\begin{tabular}{|c|c|c|c|}
\hline Source Type & Sources & Intended use of the resource & Participant statement / Log notes \\
\hline \multirow[t]{3}{*}{$\begin{array}{l}\text { Environmental } \\
\text { Resources }\end{array}$} & Teacher & Understanding the subject & $\begin{array}{l}\text { My teacher is the first person to } \\
\text { explain the subject and explains } \\
\text { the subject logically. }\end{array}$ \\
\hline & \multirow[t]{2}{*}{ Sister } & $\begin{array}{l}\text { Developing a logical } \\
\text { approach to } \\
\text { incomprehensible issues }\end{array}$ & $\begin{array}{l}\text { My sister is very important to me } \\
\text { as a helper. I can always ask about } \\
\text { things I don't understand. She } \\
\text { explains the logic of operations } \\
\text { and subjects. }\end{array}$ \\
\hline & & $\begin{array}{l}\text { Finding practical solutions } \\
\text { for questions }\end{array}$ & $\begin{array}{l}\text { My sister shows practical ways to } \\
\text { solve questions. }\end{array}$ \\
\hline \multirow[t]{2}{*}{$\begin{array}{l}\text { Written } \\
\text { Resources }\end{array}$} & Test books & $\begin{array}{l}\text { See more types of } \\
\text { questions }\end{array}$ & $\begin{array}{l}\text { It allows me to see more types of } \\
\text { questions after a good grasp of } \\
\text { how to solve the questions. }\end{array}$ \\
\hline & $\begin{array}{l}\text { Subject } \\
\text { summary } \\
\text { diagrams }\end{array}$ & $\begin{array}{l}\text { Quickly remembering the } \\
\text { forgotten part while } \\
\text { solving questions }\end{array}$ & $\begin{array}{l}\text { When I forgot some points, I can } \\
\text { look and remember immediately } \\
\text { and solve the questions. They're } \\
\text { very useful. }\end{array}$ \\
\hline \multirow[t]{2}{*}{$\begin{array}{l}\text { Internet } \\
\text { Resources }\end{array}$} & $\begin{array}{l}\text { YouTube } \\
\text { channels } \\
\text { (subject } \\
\text { narration) }\end{array}$ & $\begin{array}{l}\text { Understanding the subject } \\
\text { better and not forgetting it }\end{array}$ & $\begin{array}{l}\text { Youtube is very useful to me. I } \\
\text { listen to the subject that I heard } \\
\text { from my teacher from other } \\
\text { teachers on Youtube. In this way, I } \\
\text { understand the subject better, and } \\
\text { I do not forget it. }\end{array}$ \\
\hline & $\begin{array}{l}\text { YouTube } \\
\text { channels } \\
\text { (Question } \\
\text { solution) }\end{array}$ & $\begin{array}{l}\text { Finding practical solutions } \\
\text { for questions }\end{array}$ & $\begin{array}{l}\text { I learn and comprehend practical } \\
\text { ways of solving questions. }\end{array}$ \\
\hline
\end{tabular}

As presented in Table 1, it was determined that P1 benefited from three different types of resources in learning mathematics: environmental resources, written resources and internet resources. As environmental resources, it was found that the math teacher and the sister are important resources for P1. Looking at their intended use, it has been determined that both resources help understand the subject and develop a logical approach. In addition, it was determined that her sister was an effective resource in "offering her practical ways to solve questions". The written resources used by P1 consist of test books and subject summary diagrams. While the purpose of using test books is to see more questions types, subject summary diagrams 
are used to remember the forgotten points while solving questions immediately. The internet resources used by P1 consist of Youtube channels, which are used to find practical solutions for questions, understand the subject better, and not forget it.

In the semi-structured interview with P1, the participant was asked to draw a schematic representation of the resources she used. The schematic representation of the resource system (SRRS) of the mathematics learning process drawn by P1 is given in Figure 3.

Figure 3

SRRS on the mathematics learning process drawn by P1: (a) Original SRRS (b) English SRRS

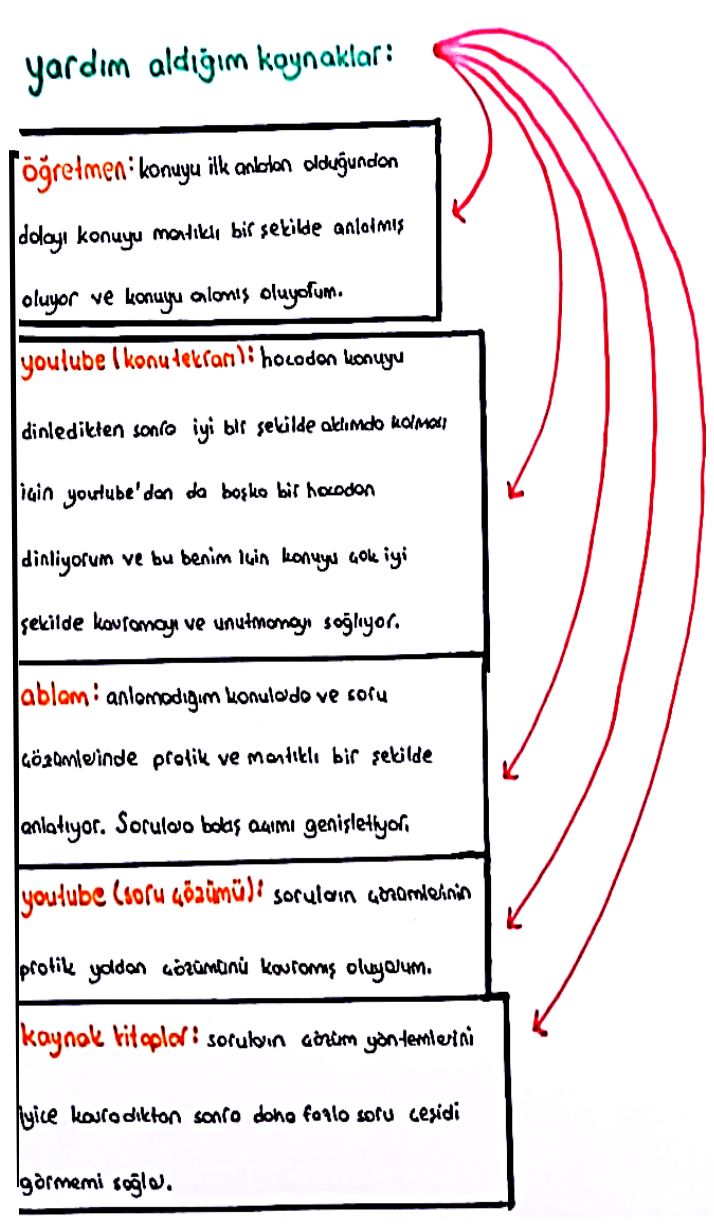

(a)
Resources I Get Help From:

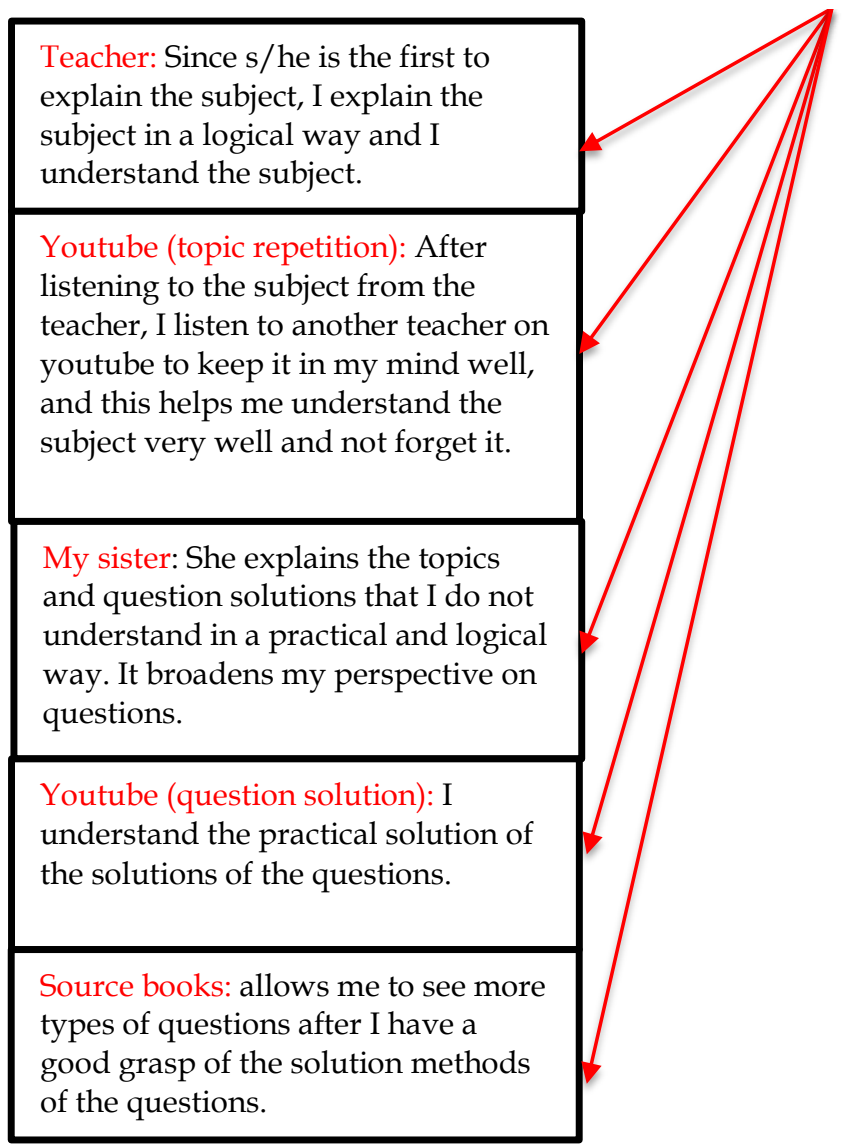

(b)

As can be seen from the Figure 3, P1 presented the resources she used in the mathematics learning process in a list and added notes on the reasons for using them. It has been determined that the resources and usage purposes stated in the SRRS are consistent with the resources stated in the interviews and mathematics learning diaries. In addition, in the clinical interviews with P1, it was examined whether the order of the resources specified in the SRRS has any meaning. In the schematic representation P1 drew, she stated that she prioritized the resources and her most important resource was her mathematics teacher. It was determined that P1 reinforced the subject by watching other course videos on YouTube after learning the subject from her teacher. In addition, in the clinical interviews, P1 stated that she mostly used the internet resources in the process of learning mathematics: I spend more time on YouTube channels while studying mathematics". P1's math learning diary also supports this finding. It has been determined that the most used resource by P1 in the diary is YouTube channels. The third resource of P1 in the SRRS diagram is her sister. P1 stated that she received support from her sister for the subjects she could not understand from her teacher's explanation or YouTube videos. It was determined that her sister offered logical and practical solutions for the questions she could not solve. The resource at the 
bottom of the SRRS drawn by P1 is the test books that the participant named sourcebooks.

In the clinical interviews, questions about the criteria for determining the test books she used were asked P1. P1 stated that she preferred the books her mathematics teacher and her sister recommended when choosing the test books she would use.

"...I mostly proceed with the books recommended by my teacher. There are also resources my sister recommended. Since my sister is in the 12th grade, she has gone through this stage and has experience. So I also take the resources she recommends...."

It is understood that mathematics teacher and sister resources, which are two important environmental resources for P1, also play a guiding role in her determining written resources. In this direction, the photographs which are taken from P1's study desk and library were examined. It was determined that P1 had the test book recommended by her teacher on her study desk. In the clinical interviews, it was determined that the participant actively used the resource suggested by her teacher as a test book and kept it on her desk for easy access. In P1's diary, it was seen that the number of resources related to mathematics courses was higher than the number of resources related to other courses. In addition, most of the mathematics resources in her library are the test books recommended by her sister. In this respect, it can be said that both her teacher and her sister played an active role in the process of choosing the test books used by P1. Another criterion that P1 pays attention to when determining the test books is the difficulty level of the questions in the resource.

"When choosing my test book, I do not attach great importance to the fact that it consists of new generation questions. Because they are very difficult and I cannot solve very much... I usually buy the test books with intermediate questions."

It was determined that P1 did not prefer the books with high difficulty level questions while choosing the test book but mostly used the test books with medium difficulty questions. Besides, it was determined that P1 had difficulties solving the contextual and skill-based questions expressed as mathematical literacy questions and therefore did not use the resources based on these questions. Photographs of the two questions that the participant liked most and found original in the test book were taken to examine the question types in the test books P1 preferred in-depth and reflectively. It has been determined that both questions do not require an association with life and can be solved by performing a series of mathematical operations. In this respect, it can be said that P1 prefers to solve only questions that require mathematical operations rather than solving contextual and skill-based questions that require an association with life. The interviews made about this examined whether P1 attaches importance to associating mathematical knowledge with life. P1's thoughts on associating mathematical knowledge with life are as follows:

"I do not attach importance to associating the mathematical knowledge with life; I do not wonder what it does for me in life. 'What will this subject do for me?' I find questions like this very silly. After all, we learn because it will help us in any way. That's why I don't care. I've never looked into what works for me. Sometimes I come across such information on the Internet, but I am not interested..."

The explanation of P1 shows that she does not find it necessary and important to associate the mathematical knowledge she learned in the lesson with life. It can be said that the important thing for P1 is to use the procedural aspect of mathematics and to improve herself in this direction. It is understood that this situation is also effective in determining the resources that P1 will use.

As a result of holistic and analytical analyses of the findings obtained from different data collection tools, two resource usage schemes belonging to P1 were reached. Some components identified in these schemes are presented in Table 2. 
Table 2

Findings related to the components of $P 1$ 's resource utilization scheme

\begin{tabular}{ll}
\hline Components of the usage scheme \\
\hline The purpose of & Ability to solve different \\
action (1) & types of questions \\
Theorem in action & $\begin{array}{l}\text { It is important to see the } \\
\text { different types of questions } \\
\text { and to understand the }\end{array}$ \\
& $\begin{array}{l}\text { solution methods. } \\
\text { The concept in }\end{array}$ \\
action (1) & Different types of questions \\
\end{tabular}

Participant statement / Diary notes

I aimed to understand the solution method of all problems.

I have seen many kinds of questions and learned how to solve them.

I understand how to solve questions

...because I saw many examples of questions, I

understood how they were solved.

I have a good grasp of the ways to solve the problems

Now that I know how to solve questions, I can solve more questions.

I saw the methods of solving the questions

Action rules (1) Take advantage of YouTube

Test books allow me to see more types of channels and quiz books to questions.

see different types of

questions

Go to resources with

medium difficulty questions.

I usually buy test books with intermediate

questions."

Developing practical
solutions for different types

The purpose of

action (2)

Theorem in action

of questions

Practical solutions should be

determined for each

question type. It is not so

important to know what the

subject is for in real life.

The concept in

action (2)

Action rules (2)
Practical solution

Take advantage of YouTube channels to learn practical solutions and apply what you have learned in test books.

Get help from your sister for the practical solution of questions.
I aimed to learn easy ways to solve problems.

I learned the short solution of some question forms

"I do not attach importance to associating the mathematical knowledge in the lesson with life; I do not wonder what it does for me in life.

I understood how to solve the questions shortly.

By watching the solved questions on the YouTube channel, I saw the solution of all kinds of problems with the short method, and then I solved a question to reinforce it.

My sister shows practical ways to solve questions.

When Table 2 is examined, two different purposes were determined in the components of P1's resource usage schemes in the mathematics learning process: "Ability to solve different types of questions" and "Developing practical solutions for different types of questions". When the operational invariants aimed at solving different types of questions are examined, "It is important to see the different types of questions and understand the solution methods" the theorem and "concept of different types of questions and solutions" have been identified. To achieve the purpose of solving different types of questions, P1 takes the action rule "Benefit from YouTube channels and test books" as a basis. In addition to these, P1 aims to develop practical solutions for different types of questions in the resource usage scheme. The basis of this goal is to determine "Practical solutions for each question type as operational invariants. With the theorem knowing what the subject is for in real life is not so 
important "practical solution" concept is included. It was determined P1 uses the action rules "Benefit from YouTube channels and apply what you learn in test books" and "Get help from your sister for the practical solution of questions" to learn the practical solutions of the different types of question.

\subsection{Findings Regarding the Participant (P2) with a High Level of Mathematical Literacy}

In line with the first problem of the study, the resources used by the participant with low mathematical literacy level in the mathematics learning process were determined, and some components of the usage schemes related to these resources were determined. When the semistructured interviews and the mathematics learning diaries filled by the participant are examined, the findings regarding the resources used by P2 are presented in Table 3.

Table 3

Findings regarding the resources used by $P 2$

\begin{tabular}{|c|c|c|c|}
\hline Source Type & Sources & $\begin{array}{l}\text { Intended use of the } \\
\text { resource }\end{array}$ & Participant statement / Log notes \\
\hline \multirow[t]{2}{*}{$\begin{array}{l}\text { Individual } \\
\text { resources }\end{array}$} & Herself & $\begin{array}{l}\text { Associating the learned } \\
\text { subject to life }\end{array}$ & $\begin{array}{l}\text { I think about where the things I learned can be } \\
\text { used. }\end{array}$ \\
\hline & & & $\begin{array}{l}\text { Sometimes I realize that I use the subject I } \\
\text { learned in class in my daily life. For example, } \\
\text { when my teacher asks a question in class, I } \\
\text { calculate the probability of my turn. }\end{array}$ \\
\hline \multirow[t]{5}{*}{$\begin{array}{l}\text { Environmental } \\
\text { Resources }\end{array}$} & Teacher & $\begin{array}{l}\text { Understanding the } \\
\text { subject and getting } \\
\text { support in solving } \\
\text { questions }\end{array}$ & $\begin{array}{l}\text { My teacher helps me both understand the } \\
\text { subject and solve the questions that I cannot } \\
\text { solve. }\end{array}$ \\
\hline & & $\begin{array}{l}\text { Associating the learned } \\
\text { subject to life }\end{array}$ & $\begin{array}{l}\text { My teacher gives examples about life in the } \\
\text { lesson. }\end{array}$ \\
\hline & Brother & $\begin{array}{l}\text { Get support in } \\
\text { problem-solving } \\
\text { Associating the learned } \\
\text { subject to life }\end{array}$ & $\begin{array}{l}\text { I usually ask the brother questions that I can't } \\
\text { solve. I understand better when he tells it. } \\
\text { Since my brother said, 'Look, it works here in } \\
\text { daily life, too,' I associate it with a better life. }\end{array}$ \\
\hline & Cousin & $\begin{array}{l}\text { Get support in } \\
\text { problem-solving }\end{array}$ & $\begin{array}{l}\text { My cousin is a math teacher. I also ask him } \\
\text { questions that I can't solve. }\end{array}$ \\
\hline & Friend & $\begin{array}{l}\text { Exchanging ideas for } \\
\text { solving problems }\end{array}$ & $\begin{array}{l}\text { I have a friend; we ask each other questions } \\
\text { we can't solve. We think together. }\end{array}$ \\
\hline \multirow[t]{2}{*}{$\begin{array}{l}\text { Written } \\
\text { Resources }\end{array}$} & Test books & $\begin{array}{l}\text { Understanding the } \\
\text { subject }\end{array}$ & $\begin{array}{l}\text { I am solving questions to understand the } \\
\text { subject. If I can solve difficult questions about } \\
\text { the subject, I see that I understand the subject. }\end{array}$ \\
\hline & & $\begin{array}{l}\text { Associating the learned } \\
\text { subject to life }\end{array}$ & $\begin{array}{l}\text { I generally use resources with new generation } \\
\text { questions. While solving these questions, I } \\
\text { visualize what I have read in life. It helps me } \\
\text { relate the subject to life. }\end{array}$ \\
\hline $\begin{array}{l}\text { Visual Argument } \\
\text { resources }\end{array}$ & Comics & $\begin{array}{l}\text { Associating the learned } \\
\text { subject to life }\end{array}$ & $\begin{array}{l}\text { I had a math book. In some places, it } \\
\text { explained the subject with comics. I } \\
\text { understood where that subject mattered to us. }\end{array}$ \\
\hline \multirow[t]{2}{*}{ Internet resources } & $\begin{array}{l}\text { YouTube } \\
\text { channels }\end{array}$ & $\begin{array}{l}\text { Understanding the } \\
\text { subject }\end{array}$ & $\begin{array}{l}\text { I learn things I don't understand by listening } \\
\text { to YouTube channels. }\end{array}$ \\
\hline & $\begin{array}{l}\text { Brief subject } \\
\text { summaries }\end{array}$ & $\begin{array}{l}\text { Get support while } \\
\text { solving questions }\end{array}$ & $\begin{array}{l}\text { When I can't solve the questions, I look at the } \\
\text { tables summarizing the subject on the Internet. } \\
\text { It helps me a lot because it's a summary. }\end{array}$ \\
\hline $\begin{array}{l}\text { Interdisciplinary } \\
\text { resources }\end{array}$ & $\begin{array}{l}\text { Other } \\
\text { courses }\end{array}$ & $\begin{array}{l}\text { Associating the learned } \\
\text { subject to life }\end{array}$ & $\begin{array}{l}\text { Sometimes I associate the information in other } \\
\text { courses with mathematics. We use } \\
\text { mathematics in subjects such as maps and } \\
\text { scales, especially in geography. }\end{array}$ \\
\hline
\end{tabular}


According to Table 3, it was determined that P2 benefited from six different types of resources in the mathematics learning process: individual resources, environmental resources, written resources, visual argument, internet resources and interdisciplinary interaction. As environmental resources, it was found that mathematics teacher, brother, cousin and friend are important resources for P2. Considering the purposes of usage, it has been determined that these environmental resources are used to get support in solving questions and to associate the subject with life. P2 stated that she is also a resource, and it has been determined that she spends time for individual thinking to associate the learned subject with life. P2 preferred test books as a written resource to understand the subject and associate it with life.

Similarly, it was determined that she used YouTube channels, one of the types of internet resources, to understand the subject and used brief subject summaries to get support while solving the questions. P2 used comics to relate the mathematical subject to life. In addition, it has been determined that P2 associates mathematics with the subjects she learned in other lessons to associate the subject with life and create interdisciplinary interaction. In addition to these, P2 was asked to draw a schematic representation of the resources she used. The schematic representation of the resource system (SRRS) of the mathematics learning process drawn by P2 is given in Figure 4.

Figure 4

SRRS on the mathematics learning process drawn by P2: (a) Original SRRS (b) English SRRS

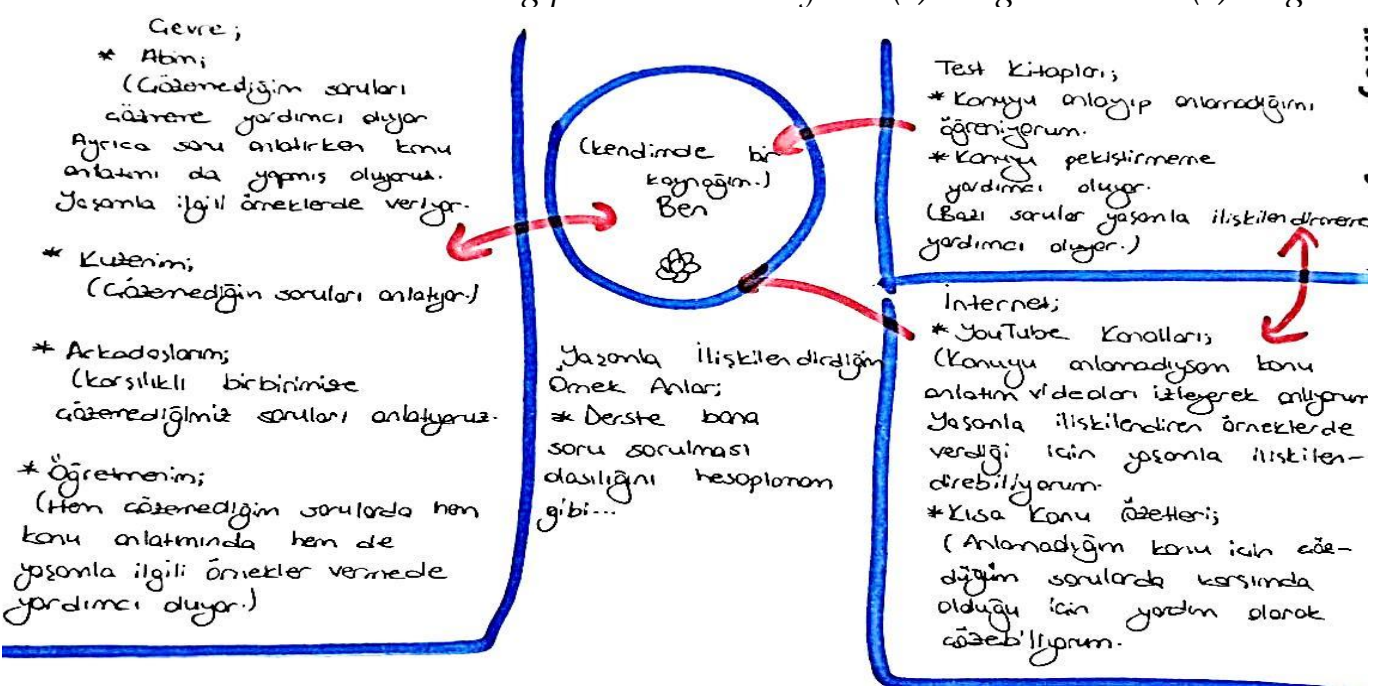

(a)

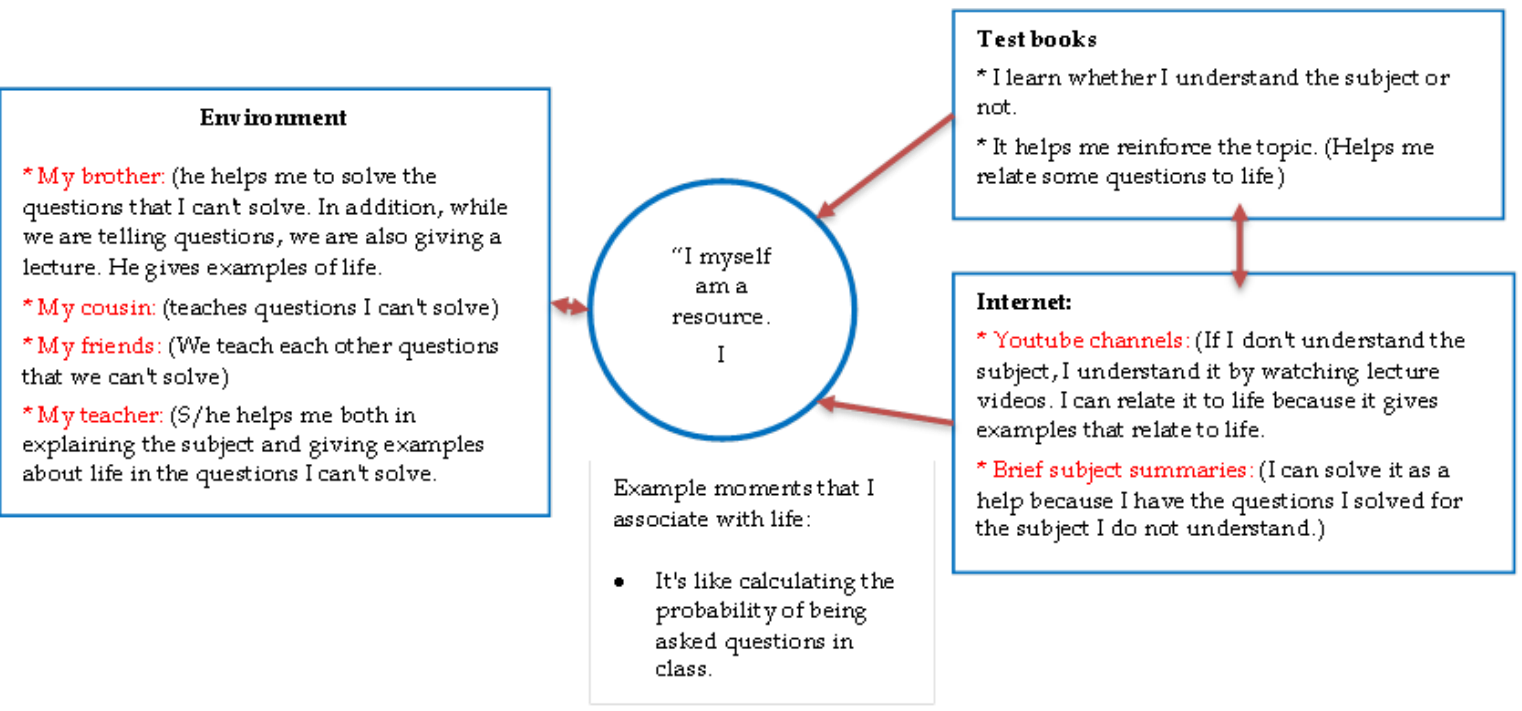

(b) 
As shown in Figure 4, P2 grouped the resources she used in the mathematics learning process by dividing them into certain categories. In this schematic representation, P2 stated that she was also a resource and placed herself in the center of her resources. In the clinical interviews, she gave the following explanation to the question about how she evaluated herself as a resource:

"I am a resource. I think what I learned in mathematics will be useful for me later. Other resources help me do this. Sometimes I realize that I use the subject I learned in class in my daily life. For example, when my teacher asks a question in class, I calculate the probability of my turn."

P2 emphasized the period she set aside to think about the association between mathematics and life and evaluated herself as a resource in this process. In addition, during the interviews, P2 stated that her most important resource was herself and that all other resources supported her. P2 has created links between the resources she mentioned in the SRRS with one-way and two-way arrows. In the clinical interviews, the following dialogue about the meaning of these connections was made:

Researcher: In the SRRS, some resources include one-way arrows and some two-way arrows. Is there any special meaning in the usage of these arrows?

P2: Yes, there is. The resources with double-sided arrows are actually interconnected.

Researcher: What kind of association is there? For example, can you explain the association between test books and internet resources?

P2: For example, if there are questions that I can't solve in the test books, I look at the brief subject summaries on the Internet. When I remember the subject, I immediately go back to the test book. Or I solve questions about the subject I listen to on Youtube in my test book.

Researcher: So what does the bidirectional link between the "I" resource and the "environmental resources" mean?

P2: For example, when there are questions that we cannot solve with my friend, we tell each other. Or we discuss where we can use that subject while studying math with my brother. But since the test books only contributed to me, I showed it with a one-way arrow.

It has been determined that each of the resources specified in the SRRS is related to the "I" resource and that these resources support the I resource. In addition, there is a mutual interaction between P2 and environmental resources. Differently, P2 is affected by environmental resources and affects these resources. In addition, it has been determined that the double-sided arrow used between the test books and internet resources means that the usage of both resources takes place in a loop.

When he findings obtained from the different data collection tools were evaluated together, two usage schemes of P2 were reached. Some components of these schemes are presented in Table 4. According to Table 4, when the components of the resource usage schemes in P2's mathematics learning process were examined, two different purposes were identified: "Associate the subject to life" and "Solve mathematical literacy questions and difficult questions". When the operational invariants to associate the subject with life are examined, the theorem "Knowing what the subject is for makes it the center of attention." and the concept "associating with life" have been identified. P2 has developed action rules that require using five different types of resources (individual resource, visual argument, environmental resource, written resource and interdisciplinary interaction) to achieve the purpose of associating the subject with life. In addition to these, P2 aimed to solve mathematical literacy questions and difficult questions in the resource usage scheme. Based on this goal, there are the theorem "If difficult questions can be solved, the subject is understood" and the concept "Mathematical literacy questions and difficult questions" as operational invariants. To achieve this goal, it was determined that P2 uses action rules "Start with the test books with the easy questions and then solve the test books with the difficult questions." and "Strive to solve difficult questions and focus on mathematical literacy questions." 
Table 4

Findings regarding the components of the P2 usage scheme

\begin{tabular}{|c|c|}
\hline \multicolumn{2}{|c|}{ Components of the usage scheme } \\
\hline $\begin{array}{l}\text { The purpose of } \\
\text { action (1) }\end{array}$ & $\begin{array}{l}\text { Associating the learned } \\
\text { subject to life }\end{array}$ \\
\hline $\begin{array}{l}\text { Theorem in action } \\
\text { (1) }\end{array}$ & $\begin{array}{l}\text { Knowing what the subject is } \\
\text { for makes it the center of } \\
\text { attention. }\end{array}$ \\
\hline $\begin{array}{l}\text { The concept in } \\
\text { action (1) }\end{array}$ & Associating with life \\
\hline Action rules (1) & $\begin{array}{l}\text { Take the time to think about } \\
\text { where the subject works and } \\
\text { use the subject you learned } \\
\text { daily. } \\
\text { Think about the examples } \\
\text { given in the comics in your } \\
\text { book and the examples your } \\
\text { teacher and brother gave. } \\
\text { Notice what math topics are } \\
\text { good for in other lessons } \\
\text { Prioritize solving contextual } \\
\text { and skill-based questions. }\end{array}$ \\
\hline
\end{tabular}

The purpose of the action (2)

Theorem in action

The concept in action (2)

Action rules (2)

\section{Solve mathematical literacy} questions and difficult questions

If difficult questions can be solved, the subject is deemed to be understood.

\section{Mathematical literacy questions and difficult questions.}

Start with the test books with the easy questions and then solve the test books with the difficult questions.

Strive to solve difficult questions, focus on mathematical literacy questions.
Participant statement / Log notes

It helps me relate the subject to life. I'm learning where it will work for me.

When I learn what a topic is good for, that topic is more interesting to me.

I think about where the things I learned can be used. I make time for this sometimes....Sometimes I realize that I use the subject I learned in class in my daily life. Since my brother said, 'Look, it works here in daily life, too,' I associate it with life better. ...In comics about mathematics, I understood where the subject was useful for us.

Sometimes I associate the information in other courses with mathematics.

While solving new generation questions, I visualize what I read in life. It helps me relate the subject to life.

\section{I generally use the resources with new} generation questions.

I have the test books called "Masters" with very difficult questions. I am specifically trying to solve them.

I am solving questions to understand the subject. If I can solve difficult questions about the subject, I see that I understand the subject.

First, I solve the easy questions; then, I look at the test books with difficult and new generation questions.

I generally use the resources with new generation questions.

I have test books called "Masters" with very difficult questions. I am specifically trying to solve them.

\subsection{Comparison of the Findings of Participants with Low (P1) and High (P2) Mathematical Literacy Levels}

In line with the third problem of the study, the resources used by the participants with low (P1) and high (P2) mathematical literacy levels in the mathematics learning process and the usage schemes of these resources were compared. According to the findings, it was determined that some types of resources used by both participants were similar. P1 benefits from three different resources in the mathematics learning process: environmental resources, written resources and 
internet resources. On the other hand, P2, who has a high mathematical literacy level, uses each of the resource types that $\mathrm{P} 1$ uses but also makes use of three different types of resources. The resource types that P2 uses differently from P1; individual resource, visual argument and interdisciplinary interaction.

When the components of the resource usage schemes of the participants were examined, significant differences were detected. While P1 uses a resource system to develop practical solutions for different question types, P2 uses resources to associate the subject to life. When the operational invariants based on these purposes are examined, P1 adopts the theorem "Practical solutions should be determined for each question type. It is not so important to know what the subject is for in real life. On the other hand, P2 attaches importance to associating the subject with life based on the theorem "Knowing what the subject is for makes it the center of attention." In this direction, it was determined that the purpose of action and operational invariants of the resource usage schemes of the participants differed significantly from each other. In addition, both of the participants benefit from the environmental resources as a rule of action to achieve the stated goals. However, whereas P1 prefers her sister, one of her environmental resources, "to learn the practical solutions of the questions,"; P2 prefers her brother, one of her environmental resources, "For giving examples associating mathematics and life.". In this context, although some resource types used by both participants are similar, it has been determined that the usage schemes and operational invariants are different from each other.

In terms of the components of the second resource usage schemes of the participants, it was determined that there were differences in the participants' purpose of action for solving questions. While P1 aims to solve different types of questions, P2 aims to solve mathematics literacy questions and difficult questions. When the operational invariants of these actions are examined, it was found that P1 adopted the theorem "It is important to see different types of questions and to understand the solution methods." In P2's resource usage scheme, the theorem "If difficult questions can be solved, the subject is understood." works. In this direction, significant differences emerged between the action rules of the participants' usage schemes. While P1 prefers the resources with intermediate difficulty and different types of questions to achieve her goal, P2 focuses on solving the resources with contextual and difficult questions. In this context, it can be said that the two participants with low and high mathematical literacy levels have significant differences in the resource usage schemes and operational invariant elements of these schemes.

\section{Discussion and Conclusion}

This study examined and compared the documentation processes of two students with high mathematics achievement but low and high mathematical literacy levels. According to the results obtained from the research, some types of resources used by the two participants with low and high mathematical literacy levels were similar. However, it was determined that there were significant differences in the elements of the resource usage schemes of the participants. In the study conducted by Yeğit (2019), it was determined that although some students had high mathematics achievement, their mathematical literacy level was not high. Similar findings were made in our study, but it was determined that there were significant differences in the resource usage schemes of the participants. Differences from this study can be considered as an extension of the reference study.

Both of the participants benefitted from environmental resources, written resources and internet resources in the process of learning mathematics. However, in the resource system of the participant with high mathematical literacy level and these resource types, individual resource, visual argument, and interdisciplinary interaction were also included. It was determined that the participant with a high mathematical literacy level used these three different resources to associate mathematics with life. As a matter of fact, the student needs to intervene in life events with the learned mathematics and eliminate the "disconnection" between school mathematics and daily life (Altun \& Bozkurt, 2017). For this reason, the ability of individuals to produce mathematical 
solutions to the problems they encounter in real life and make mathematical knowledge functional by associating it with life has become the current goal of mathematics teaching (Altun et al., 2018). Another difference in the resource systems of the participants is related to the resource types they consider important. It was determined that the most important resource of the participant with low mathematical literacy level was the mathematics teacher, and she preferred the written resources suggested by her teacher more. It has been concluded that the most important resource of the participant with a high mathematical literacy level was herself. The participant performed individual thinking activities about using mathematical knowledge in real life and considered herself a resource in these activities. In this context, it can be said that the type of resource in the center of the resource system of the students is effective on their mathematical literacy skills. In this direction, the mathematics teacher's approach and resource recommendations are very important to increase the mathematics literacy levels of the students, whose most important resource is the mathematics teacher and who prioritize the resources suggested by the teacher. In addition, it is understood that individual thinking activities carried out by the students about the usage of mathematics in real life can be effective in mathematical literacy. As a matter of fact, giving the student the opportunity to choose the most suitable one for his/her own understanding-comprehension structure and the ability of the student to design their own learning process is a situation that should be considered important (Yenilmez \& Çakır, 2005). Therefore, in today's generation, it has become more important to teach mathematics rather than teaching mathematics. This study supports this situation. Because while the mathematics literacy of the student who primarily referred to the mathematics teacher in the mathematics learning process was low, the mathematics literacy of the student who associated mathematics with life based on himself/herself and his/her learning process was higher. In this respect, mathematics teachers need to guide student-specific resource selection. In this direction, it is vital that a mathematics teacher first determine the students' learning, receive an education for this, and then direct the students to the resources that can establish a relationship between mathematics and life, taking into account their learning styles. The findings of this study may shed light on studies on the subject. In line with the results of the study, it can be deduced that it is crucial to associate mathematics with life in the teaching process and the learning process. Similarly, Kabael and Barak (2016) emphasized the importance of teaching mathematics by associating it with daily life. Khaerunisak et al. (2017) stated that realistic mathematics education, which associates mathematics to life, effectively increases students' mathematical literacy levels. In this respect, the result of the study supports the literature.

In the study, resource usage schemes were determined for each participant. When these schemes are examined, it has been determined that although some of the resource types used by the participants are similar, there are significant differences in the elements of the resource usage schemes. One of the purposes of resource usage for the participant with a high mathematical literacy level was to associate mathematics with life. It has been concluded that the participant with a low mathematical literacy level cared about finding practical solutions to the questions and did not attach importance to associating mathematics with life. Mathematical literacy is an important tool that enables one to associate mathematics with daily life and solve real-life problems mathematically (McCrone \& Dossey, 2007). In this direction, it can be said that students' purpose to associate mathematics with life in the resources they use plays an important role in the development of mathematical literacy. The type of questions asked to students in the exams held in schools primarily measure mathematical operation skills (Fatih \& Bekdemir, 2017). This situation directs the student primarily to process the learned information in the world of mathematics. However, it can be understood that the mathematical literacy level of the student who explores the relationship between mathematics and life by revealing his/her curiosity and prefers to use resources for this in the mathematics learning process is high. In addition, both participants benefitted from environmental resources in the process of learning mathematics. However, it was determined that the participant with a high mathematical literacy level preferred 
her brother from the environmental resources because she gave examples associating mathematics and life. In contrast, the participant with a low mathematical literacy level received help from her sister to learn practical solutions to the questions. Similarly, both participants used a test book, one of the written resources. It was determined that the participant with a high mathematical literacy level preferred the test books with daily life problems and contextual questions. On the other hand, the participant with a low mathematical literacy level preferred the test books that contain question types unrelated to life and require only a series of mathematical operations for their solution. In this direction, although the participants used similar resource types, it is understood that the purposes of the resource usage schemes differed significantly from each other. As a matter of fact, Baştürk-Şahin et al. (2020) stated that although individuals use the same resource, the resource usage schemes developed by them may differ. It is understood that this difference in the resource usage schemes of the participants is related to the tendency to associate mathematical knowledge with life, and this situation affects their mathematical literacy skills.

In the study, the theorems and concepts in action were reached by examining the operational invariants of the resource usage schemes of the participants. The participant with a high mathematical literacy level focused on the theorem that knowing what the subject is for will make that subject the center of attention in the resource usage scheme. Related to this, Özgen and Pesen (2008) stated that daily life problems and activities prepared based on this increase students' interests and desires for a mathematics course. This situation coincides with the result obtained from the research. In addition, it was determined that the participant with a high mathematical literacy level cared about associating mathematical knowledge with life and tended to use mathematical knowledge actively in daily life. This participant speculated about the place of mathematics in real life and created interdisciplinary interaction by associating mathematics with the information learned in other courses. In their study, Karakuş et al. (2017) determined that the interdisciplinary approach has benefits such as associating the subject with real life, attracting attention, making the subject concrete, providing permanence, and increasing achievement, as well as the convenience it provides in learning. Kander (2003) found that students who study with an interdisciplinary approach do not have difficulty solving problems in daily life, including mathematics and science, and can communicate effectively with individuals from different disciplines. It was determined that the participant with a low mathematical literacy level did not engage in any activities related to establishing an association between mathematics and life and deemed these activities unnecessary. Indeed, mathematical literacy requires students to perform arithmetic operations and recognize mathematical problems in the context of real life and express them mathematically (Satic1, 2008). In this case, it was concluded that the theorems that form the basis of the resource usage schemes of students with low and high mathematical literacy levels differ significantly from each other. For this reason, it is understood that for the development of students' mathematical literacy skills, the theorem in action should be used, and the importance of associating mathematics with life should be emphasized.

In the second resource usage scheme determined for the participants in the study, it was determined that the participant with a high mathematical literacy level aimed to solve mathematical literacy questions and difficult questions. This usage scheme of the participant was based on the theorem that the subject is understood if difficult questions can be solved. The participant with low mathematical literacy, on the other hand, tended to recognize the question types and memorize the solutions. This participant focused on the theorem that it is important to see different question types and understand the solution methods. Martin (2007), on the other hand, criticized students' learning mathematics by rote away from real life and suggested a mathematics learning process intertwined with life. Magen-Nagar (2016), on the other hand, determined that students with a high mathematical literacy level use the memorization strategy less. As a matter of fact, mathematical literacy questions require students to reason and produce new solution strategies (OECD, 2018). In this direction, it is understood that solving mathematical literacy problems is effective for developing mathematical literacy skills. It is important to include 
mathematical literacy questions in the resources and textbooks recommended to students. Gellert (2004) stated that the learning process using daily life problems makes a significant contribution to gaining mathematical literacy. Şirin and Yildız (2020) emphasized the importance of including PISA questions in mathematics textbooks. However, as a result of their study, it was determined that the mathematical literacy level of the questions in the mathematics textbooks in Turkey is low. In addition, Yeğit (2020) compared the questions in Turkish and German mathematics textbooks. It was determined that the German textbooks include questions about each of the mathematical literacy processes. Still, the Turkish textbooks do not include the questions related to the interpretation process that requires students to transfer mathematical knowledge to a real-life context. In this respect, it is understood that it is important to solve mathematical literacy questions and include these questions in the resources used to develop students' mathematical literacy skills.

In line with the results obtained from the research, it is understood that the theorems in the resource usage schemes of students with low and high mathematical literacy differ in terms of attaching importance to associating mathematics with life. In this direction, to increase the mathematical literacy level, the importance and necessity of associating mathematical knowledge with life should be emphasized to students. Then, the resources and usage schemes used by the students should be shaped according to this theorem. The usage of resources that will enable students to associate mathematics and life should be supported in the learning processes at schools and outside of the schools. Environments should be created that enable students to think individually about mathematics in real life or exchange ideas with environmental resources such as teachers, family, and friends. By increasing the variety of resources used by students in the mathematics learning process, comics and visual arguments that enable them to establish an association between mathematics and life can be included. Mathematical literacy questions and solutions should be included in the learning and teaching process. Activities can enable students to make connections between mathematics and other lessons by interacting between disciplines. In this study, the students' resource usage scheme components were obtained at the end of a onemonth data collection process. More detailed information about the resource usage schemes of the participants can be obtained by carrying out a longer data collection process in future studies. In line with the study results, it was thought that there might be a relationship between the tendency to learn mathematics and the usage of resources. Studies that can reveal this relationship can be carried out. This study was carried out with high school students. Considering that students' habits related to individual resource usage and resource selection may emerge at their previous education levels, the study carried to the last years of secondary school or even primary school is valuable for the literature. However, this study was limited to two students in Turkey. It may also be valuable to compare the resource usage schemes of students in Turkey with those in a country with high mathematical literacy.

Acknowledgements. This study is an extended version of the paper presented at the VI. International European Conference on Social Sciences.

\section{References}

Ak1ll, E. (2020). The effect of mathematics literarcy education on academic success and epistemological belief in 7 th grade students (Publication No. 653453) [Unpublished Master's thesis, Bursa Uludag University-Bursa]. Council of Higher Education Thesis Center.

Akyüz, G., \& Pala, N. M. (2010). The effect of student and class characteristics on mathematics literacy and problem solving in PISA 2003. Elementary Education Online, 9(2), 668-678.

Altun, M., Aydın Gümüş, N., Akkaya, R., Bozkurt, İ., \& Kozaklı Ülger, T. (2018). Investigation of mathematics literacy skill levels of eighth grade students. Journal of Science, Mathematics, Entrepreneurship and Technology Education, 1(1), 66-88. 
Altun, M., \& Bozkurt, I. (2017). A new classification proposal for mathematical literacy problems. Education and Science, 42(190), 171-188. https://doi.org/http://dx.doi.org/10.15390/EB.2017.6916

Baştürk-Şahin, B. N., Tapan-Broutin, M. S., Trouche, L., Gueudet, G., Pepin, B., Burcu, Ç., Baştürk, N., Kontrol, Ş., Menekşe, E., \& Tapan-Broutin, S. (2020). Didaktiğe dokümantal yaklaşım [Documentary approach to didactics]. DAD-Multilingual. https://hal.archives-ouvertes.fr/hal-02725882v1

Cooney, T. J. (1999). Conceptualizing teachers' ways of knowing. In D. Tirosh (Ed.), Forms of mathematical knowledge (pp. 163-187). Springer. https://doi.org/https://doi.org/10.1007/978-94-017-1584-3_8

Çepni, S. (2007). Araştırma ve proje çalışmalarına giriş [Introduction to research and project studies]. Celepler.

Eraslan, A. (2009). Reasons behind the success of Finland in PISA: Lessons for Turkey. Necatibey Faculty of Education Electronic Journal of Science and Mathematics Education, 3(2), 238-248.

Ersoy, Y. (1997). Okullarda matematik eğitimi: Matematikte okur-yazarlık [Mathematics education in schools: Literacy in mathematics]. Hacettepe University Journal of Education Faculty, 13(13), 115-120.

Fatih, B. A. S.., \& Bekdemir, M. (2017). Analysis of mathematics teachers' questions used in examinations in terms of conceptual and operational knowledge. Ondokuz Mayis University Journal of Education Faculty, 36(1), 95-113.

Gellert, U. (2004). Didactic material confronted with the concept of mathematical literacy. Educational Studies in Mathematics, 55(1), 163-179. https:// doi.org/https://doi.org/10.1023/B:EDUC.0000017693.32454.01

Gueudet, G. (2017). University teachers' resources systems and documents. International Journal of Research in Undergraduate Mathematics Education, 3(1), 198-224. https://doi.org/10.1007/s40753-016-0034-1

Gueudet, G., \& Trouche, L. (2009). Towards new documentation systems for mathematics teachers? Educational Studies in Mathematics, 71(3), 199-218. https://doi.org/https://doi.org/10.1007/s10649-0089159-8

Gueudet, G., \& Trouche, L. (2011). Teachers' work with resources: Documentational geneses and professional geneses. In G. Gueudet, B. Pepin, \& L. Trouche (Eds.), From text to 'Lived' resources (pp. 2341). Springer. https://doi.org/https://doi.org/10.1007/978-94-007-1966-8_2

Guertin, D. (2012). Une démarche de pratique réflexive pour la construction du savoir professionnel On conçoit différemment, parce qu'on perçoit différemment [A reflective practice approach for building professional knowledge We design differently, because we perceive differently] [Unpublished Master's thesis, University of Sherbrooket]. https://www.usherbrooke.ca/pedagogie/fileadmin/sites/pedagogie/MPESDPES/Donald_Guertin.pdf

Kabael, T. (2019). Matematik Okuryazarlı̆ğ ve PISA [Mathematical Literacy and PISA]. In T. Kabael (Ed.), Matematik Okuryazarlı̆̆ ve PISA [Mathematical Literacy and PISA] (pp. 11-34). Anı.

Kabael, T., \& Barak, B. (2016). Research of middle school pre-service mathematics teachers' mathematical literacy on PISA items. Turkish Journal of Computer and Mathematics Education, 7(2), 321-349. https://doi.org/http://doi.org/10.16949/turcomat.73360

Kander, R. G. (2003, November). A successful experiment in curriculum integration: Integrated science and technology at James Madison University [Paper presentation]. 33rd Annual Frontiers in Education, Westminster, Colorado. https://doi.org/10.1109/FIE.2003.1266006

Karakuş, M., Türkkan, B. T., \& Karakuş, F. (2017). Determining science and elementary mathematics teachers' views on interdisciplinary approach. Elementary Education Online, 16(2), 509-524.

Khaerunisak, K., Kartono, K., Hidayah, I., \& Fahmi, A. Y. (2017). The analysis of diagnostic assessment result in PISA mathematical literacy based on students self-efficacy in RME learning. Infinity Journal, 6(1), 77-94. https://doi.org/10.22460/infinity.v6i1.p77-94

Kock, Z. J., \& Pepin, B. (2018, April). Student use of resources in Calculus and Linear Algebra [Paper presentation]. International Network for Didactic Research in University Mathematics, Kristiansand, Norway. https://hal.archives-ouvertes.fr/hal-01849945

Lincoln, Y. S., \& Guba, E. G. (1985). Naturalistic inquiry. Sage.

Magen-Nagar, N. (2016). The effects of learning strategies on mathematical literacy: A comparison between lower and higher achieving countries. International Journal of Research in Education and Science, 2(2), 306321.

Martin, H. (2007). Mathematical literacy. Principal Leadership, 7(5), 28-31.

McCrone, S. S., \& Dossey, J. A. (2007). Mathematical literacy--it's become fundamental. Principal Leadership, $7(5), 32-37$.

Ministry of National Education. (2019). PISA 2018 Turkey preliminary report. Education Analysis and Evaluation Reports Series. Retrieved from http://www.meb.gov.tr/meb_iys_dosyalar/2019_12/03105347_PISA_2018_Turkiye_On_Raporu.pdf 
OECD. (2010). PISA 2009 assessment and analytical framework. Author. Retrieved from https://www.oecd.org/pisa/ pisaproducts/44455820.pdf

OECD. (2018). PISA 2015 assessment and analytical framework: Science, reading, mathematic, financial literacy and collaborative problem solving. Author. Retrieved from https://www.oecd.org/education/pisa-2015assessment-and-analytical-framework-9789264281820-en.htm

OECD. (2019). PISA 2018 assessment and analytical framework. Author. Retrieved from https://www.oecdilibrary.org/docserver/b25efab8en.pdf?expires=1627993790\&id=id\&accname=guest\&checksum=E64F47A67626D4B877108A6B6B3470BE

Özgen, K., \& Pesen, C. (2008). Problem-based learning approach and students' attitudes towards to mathematics. Journal of Dicle University Ziya Gokalp Faculty of Education, 11, 69-83.

Patton, M. O. (2005). Qualitative research. John Wiley \&Sons.

Rautalin, M., \& Alasuutari, P. (2009). The uses of the national PISA results by Finnish officials in central government. Journal of Education Policy, 24(5), 539-556. https:// doi.org/10.1080/02680930903131267

Sarıoglu, B. I. (2020). Investigation of documentational geneses processes of mathematics teachers during their pre-service and in-service lives (Publication No. 640929) [Unpublished Master's thesis, Bursa Uludag University-Bursa]. Council of Higher Education Thesis Center.

Satıc1, K. (2008). Investigating the factors affecting mathematics literacy using PISA 2003 results: Turkey and Hong Kong - China (Publication No. 237729) [Unpublished Master's thesis, Balıkesir UniversityBalıkesir]. Council of Higher Education Thesis Center.

Serçe, F. \& Acar, F. (2021). A comparative study of secondary mathematics curricula of Turkey, Estonia, Canada, and Singapore. Journal of Pedagogical Research, 5(1), 216-243.

Strauss, A. L., \& Corbin, J. M. (1998). Basics of qualitative research: Techniques and procedures for developing grounded theory (2nd ed.). Thousand Oaks, Sage publications.

Şirin, B., \& Yıldız, A. (2020). The investigate of 8th grade mathematics course book according to PISA basic mathematics skills levels. Cumhuriyet International Journal of Education, 9(4), 1158-1176. http://dx.doi.org/10.30703/cije.676100

Trouche, L., Gueudet, G., \& Pepin, B. (Eds.). (2019). The 'resource' approach to mathematics education. Springer. https:// doi.org/10.1007/978-3-030-20393-1

Vergnaud, G. (1989). La formation des concepts scientifiques. Relire Vygotski et débattre avec lui aujourd'hui [The formation of scientific concepts. Reread Vygotsky and debate with him today]. Enfance, 42(1-2), 111118. https://doi.org/10.3406/enfan.1989.1885

Vergnaud, G. (1998). Towards a cognitive theory of practice. In A. Sierpinska, J. \& Kilpatrick (Eds.), Mathematics education as a research domain: A search for identity (pp. 227-240). Springer.

Yeğit, H. (2019). Analysis of mathematics literacy levels of fifth grade students. Journal of Science Mathematics Entrepreneurship and Technology Education, 2(3), 174-195.

Yeğit, H. (2020). Investigation and comparison of mathematics text books used in education in Turkey and Germany in terms of mathematical literacy (Publication No. 640256) [Unpublished Master's thesis, Bursa Uludag University-Bursa]. Council of Higher Education Thesis Center.

Yenilmez, K., \& Çakır, A. (2005). Mathematics Learning styles in middle schools. Educational Management: Theory and Practice, 44, 569-585.

Yıldırım, A., \& Şimşek, H. (2013). Sosyal bilimlerde nitel araştırma yöntemleri [Qualitative research methods in the social sciences]. Seçkin.

Yllmazer, G. (2015). The examination of the relationship between secondary students' arithmetic performance scores and their mathematics literacy in accordance with certain variables (Publication No. 396095) [Unpublished Master's thesis, Sakarya University- Sakarya]. Council of Higher Education Thesis Center.

Yin, R. K. (2013). Case study research design and methods (5nd ed.). Sage Publications. 